\title{
PELATIHAN PEMBUATAN BAHAN AJAR PADA SMP NEGERI 36 PALEMBANG
}

\author{
Evi Yulianti1), Dasrial2) \\ 1),2) Program Studi Sistem Informasi, Universitas Indo Global Mandiri \\ Jalan Jend. Sudirman No. 629 Palembang, Kode Pos : 30129 \\ Email: evi.uigm@gmail.com ${ }^{1}$, dasrial uigm@yahoo.co.id ${ }^{2)}$
}

\begin{abstract}
ABSTRAK
Bahan ajar merupakan salah satu hal yang paling penting dalam kegiatan pembelajaran, tanpa adanya bahan ajar kegiatan pembelajaran menjadi tidak efektif, baik bagi guru bagi murid. Pelatihan ini merupakan wujud nyata kegiatan pengabdian kepada masyarakat yang dilakukan oleh Dosen Ilmu Komputer Universitas Indo Global Mandiri untuk membantu para guru SMP Negeri 36 Palembang, meningkatkan kompetensi dalam kegiatan pengajaran. Komputer merupakan media yang saat ini sudah menjadi kebutuhan guru dan siswa untuk mencari referensi baik sebagai bahan tugas ataupun mencari materi pengajaran. Melalui kegiatan ini diharapkan dapat meningkatkan inovasi guru dalam menyajikan bahan ajar dan dapat meningkatkan daya serap siswa atas materi yang diajarkan serta dapat membangkitkan partisipasi aktif siswa dalam proses pembelajaran.
\end{abstract}

Kata kunci : Pelatihan Bahan, Pembelajaran, Guru

\section{PENDAHULUAN}

Terdapat banyak faktor yang dapat mempengaruhi proses pembelajaran baik dari siswa itu sendiri maupun faktor-faktor lain seperti pengajaran guru, fasilitas lingkungan serta kelembagaan. Siswa yang aktif dan kreatif didukung fasilitas serta guru yang menguasai materi dan strategi penyampaian secara efektif akan semakin menambah kualitas pengajaran.

Sekolah Menengah Pertama (SMP) Negeri 36 Palembang adalah Sekolah Menengah Pertama yang berlokasi di Jalan Ki Kemas Rindo No.89 Kertapati Palembang, Provinsi Sumatera Selatan telp (0711) 511238 Kode Pos 30258. Dari pengamatan survey dilapangan yaitu dilakukannya diskusi dan wawancara dengan kepala Sekolah dan wakil Kepala Sekolah Urusan Kurikulum, masalah utama yang dihadapi para guru-guru SMP Negeri 36 yaitu dalam memanfaatkan media pembelajaran adalah masih rendahnya kemampuan dalam membuat, mengelola dan mengunakan media berbasis Komputer.

Pelatihan pembuatan media pembelajaran berbasis komputer setelah melewati diskusi dan identifikasi kebutuhan perserta pelatihan, dalam hal ini guru-guru mengajukan materi pelatihan berupa pembuatan media Powerpoint, Excel dan E-learning membuat video pembelajaran oleh karenanya pelatihan difokuskan pada ketiga aspek tersebut yang tertuang dalam modul-modul pelatihan.

Tujuan kegiatan pelatihan ini adalah untuk meningkatkan kemampuan guru-guru SMPN 36 Palembang dalam menyusun, mengelola dan menggunakan media pembelajaran berbasis komputer. Manfaat kegiatan adalah semakin meningkatnya kemampuan guru-guru dalam membuat, mengelola dan mengunakan media pembelajaran berbasis komputer. Setelah pelatihan ini diharapkan pula terjadi peningkatan kinerja guru-guru SMPN 36 Palembang serta tersebarnya pengetahuan ini kepada guru-guru sejawat yang belum berkesempatan untuk mengikuti pelatihan.

Selain metode pembelajaran, media pendidikan memegang peran penting dalam proses pembelajaran. Sesuai dengan karakteristik KBK yang menghendaki pendayagunaan keseluruhan sumber belajar, penggunaan media diharapkan dapat meningkatkan efektivitas pembelajaran sehingga iklim pembelajaran lebih kondusif.

Belajar merupakan suatu upaya penguasaan kognitif, afektif, dan psikomotorik melalui proses interaksi antara individu dan lingkungan yang terjadi sebagai hasil atau akibat dari pengalaman dan mendahului perilaku (Sagala, 2010:30). Sedangkan menurut Hilgard (Pasaribu, 1983:59) belajar adalah suatu proses perubahan kegiatan, reaksi terhadap lingkungan, perubahan tersebut tidak dapat disebut belajar apabila disebabkan oleh pertumbuhan atau keadaan sementara seseorang seperti kelelahan atau disebabkan obat-obatan. 
Menurut Gagne dalam Margaret (Nazarudin, 2007:162) bahwa istilah pembelajaran dapat diartikan sebagai separangkat acara peristiwa eksternal yang dirancang untuk mendukung terjadinya proses belajar yang sifatnya internal. Pengertian ini mengisyaratkan bahwa pembelajaran merupakan proses yang sengaja direncanakan dan dirancang sedemikian rupa dalam rangka memberikan bantuan bagi terjadinya proses belajar.

Pembelajaran diartikan juga sebagai suatu rangkaian kejadian yang mempengaruhi peserta didik sehingga proses belajarnya dapat berlangsung dengan mudah. Cakupan pembelajaran tidak hanya terbatas pada kejadian-kejadian yang dilakukan oleh guru saja, tetapi mencakup semua kejadian yang mempunyai pengaruh langsung pada proses belajar manusia. Pembelajaran mencakup kejadiankejadian yang dihasilkan oleh media-media seperti media cetak, gambar, program audio, televisi, film, slide, komputer, dan kombinasi dari bahan-bahan tersebut. Dengan melihat ini fungsi pembelajaran bukan hanya fungsi guru atau pengajar saja, melainkan fungsi-fungsi sumber belajar lain yang dapat digunakan oleh peserta didik untuk belajar sendiri.

Menurut Mulyasa (Ismail, 2008:10), pembelajaran pada hakekatnya adalah interaksi peserta didik dengan lingkungan sehingga ada perubahan ke arah yang lebih baik. Sehingga belajar mempunyai banyak faktor yang mempengaruhinya. Belajar merupakan proses internal peserta didik dalam pembelajaran, sedang pembelajaran kondisi external belajar. Kondisi external yang dapat mempengaruhi proses belajar antara lain: bahan ajar, suasana belajar, media, dan sumber belajar itu sendiri. Bahan belajar dapat berwujud benda, suasana belajar dapat berupa kondisi gedung tempat belajar, tata ruang belajar, alat-alat belajar, media dan sumber belajar.

Oemar Hamalik (1994:57) menyatakan bahwa pembelajaran adalah suatu kombinasi yang tersusun rajin meliputi unsur-unsur manusiawi, material, fasilitas, perlengkapan, dan prosedur yang saling mempengaruhi untuk mencapai tujuan pembelajaran. Manusia yang terlibat dalam sistem pembelajaran terdiri dari sisiwa, guru, dan tenaga lainnya, misal laboran. Material meliputi buku-buku, papan tulis dan kapur, fotografi, slide dan film, audio dan video. Fasilitas perlengkapan terdiri atas ruangan belajar, audio visual dan komputer. Prosedur meliputi jadwal dan metode penyampaian informasi, praktek, belajar, ujian dan sebagainya. Tujuan pembelajaran pada hakekatnya adalah diperolehnya perubahan-perubahan tingkah laku individu. Perubahan tersebut merupakan akibat dari perbuatan belajar, bukan sebagai akibat dari kematangan.

Bentuk pembelajaran berbantuan komputer dalam multimedia Pembelajaran ini adalah mengacu pada model Tutorial (tutorial campuran antara linear dan branching). Pemilihan model multimedia yang digunakan didasarkan pada sifat materi yang kompleks dan sasaran pengguna yaitu peserta didik.

Semakin berkembangnya zaman, tingkat individualism dalam pendidikan semakin meningkat. Keinginan setiap individu untuk belajarpun demikian. Hal tersebut membutuhkan strategi tertentu untuk memenuhi kebutuhan setiap individu tersebut. Pembelajaran dengan cara klasikal tidak akan mampu memecahkan masalah tersebut. Secara maksimal karena setiap orang akan memilih belajar sesuai dengan karakternya.

Multimedia Pembelajaran Berbasis Komputer dipandang untuk menjawab masalah tersebut. Dengan bantuan multimedia yang dijalankan perangkat komputer, pembelajaran akan lebih menarik, efektif dan efisien mengingat multimedia memberikan sumbangan yang besar dalam pembelajaran.

Komputer digunakan dalam proses pembelajaran karena memberikan manfaat seperti yang dikutip dalam Ismaniati (2001:26) berikut; 1). Komputer dapat meningkatkan motivasi belajar si belajar; 2). Komputer mampu memberikan informasi tentang kesalahan dan jumlah waktu belajar serta waktu untuk mengerjakan soal-soal kepada si belajar; 3). Pembelajaran berbantuan komputer merupakan suatu usaha yang sistematik dan terencana untuk mengatasi kelemahan pada pembelajaran kelompok; 4). Pembelajaran berbantuan komputer melatih si belajar untuk teranpil memilih bagian-bagian isi pembelajaran yang dikehendaki ; 5). Pengembangan yang dirancang secara hati-hati akan bermanfaat bagi si belajar yang biasanya kurang dapat mengikuti metode pembelajaran tradisional; 6). Rasa malu adalah salah satu faktor yang menggangu si belajar yang lemah dalam usahanya untuk belajar; 7). Pembelajaran berbantuan komputer memungkinkan si belajar untuk lebih mengenal dan terbiasa dengan komputer yang menjadi semakin penting dalam masyarakat modern sekatang ini dan yang dapat memberikan bantuan yang besar dalam pelatihan di masa yang akan datang serta untuk prospek karier. 
Dengan mencermati karakteristik media berbasis komputer tersebut, bahwa penggunaan media berbasis komputer memiliki karakteristik yang relatif sama dan mendukung pembelajaran berbasis komputer yang memiliki potensi untuk digunakan sebagai media pembelajaran alternatif.

\section{METODE PELAKSANAAN PENGABDIAN}

\subsection{Materi yang diberikan}

Program Pelatihan ini adalah melakukan pelatihan pembuatan media pembelajaran menggunakan media Powerpoint, Excel dan E-learning yang dilaksanakan sebanyak 2 (dua) kali pertemuan dimulai sabtu tanggal, 30 mei 2015 dan sabtu tanggal 6 juni 2015. Yang dilaksanakan dari jam 9.00 s.d jam 16.00.

Pelatihan pembuatan media berbasis komputer bagi guru-guru SMPN 36 Palembang, dilaksanakan dengan metode ceramah, diskusi dan praktek. Diskusi dilakukan secara terbuka, Praktek langsung dilakukan didepan komputer, masing-masing perserta menggunakan laptop. Adapun materi yang akan diberikan sebagai berikut :

Tabel 1. Materi yang diberikan

\begin{tabular}{|c|c|c|c|}
\hline No & Materi & Narasumber & $\begin{array}{c}\text { Tempat } \\
\text { Pelaksanaan }\end{array}$ \\
\hline 1. & $\begin{array}{l}\text { 1. Pengenalan Materi Ms.Powerpoint } \\
\text { 2. Langkah-langkah masuk/keluar } \\
\text { Ms.Powerpoint } \\
\text { 3. Membuat Slide } \\
\text { 4. Langkah-langkah membuat Presentasi } \\
\text { 5. Membuat Animasi Menu Berjalan }\end{array}$ & $\begin{array}{l}\text { Dasrial, M.Kom } \\
\text { Anggota 3(tiga) } \\
\text { Orang } \\
\text { Mahasiswa }\end{array}$ & $\begin{array}{l}\text { Ruang Rapat } \\
\text { Sekolah }\end{array}$ \\
\hline \multirow[t]{2}{*}{2.} & $\begin{array}{l}\text { 1. Pengenalan Materi Ms.Excel } \\
\text { 2. Langkah-langkah masuk/keluar Ms.Excel } \\
\text { 3. Memilih cell atau Range } \\
\text { 4. Mengatur tinggi row dan column } \\
\text { 5. Menyimpan dan membuka File }\end{array}$ & \multirow{2}{*}{$\begin{array}{l}\text { Evi Yulianti, } \\
\text { M.SI } \\
\text { 3(tiga) Orang } \\
\text { Mahasiswa } \\
\\
\text { Evi Yulianti, } \\
\text { M.SI } \\
\text { 3(tiga) Orang } \\
\text { Mahasiswa }\end{array}$} & $\begin{array}{l}\text { Ruang Rapat } \\
\text { Sekolah }\end{array}$ \\
\hline & $\begin{array}{l}\text { 6. Membuat Tabel } \\
\text { 7. Mengenalkan Formula Dasar Ms.Excel } \\
\text { 8. Alamat Absolut, Fungsi Lookup,Fungsi } \\
\text { Logika } \\
\text { 9. Data Sort, Grafik dan gambar } \\
\text { 10. Mengatur Halaman dan Cetak }\end{array}$ & & $\begin{array}{l}\text { Ruang Rapat } \\
\text { Sekolah }\end{array}$ \\
\hline \multirow[t]{2}{*}{3.} & $\begin{array}{l}\text { 1. Instalasi Program Elearning (Moodle) } \\
\text { 2. Pengenalan Materi Elearning } \\
\text { 3. Mengenal Tampilan Portal e-learning } \\
\text { 4. Mengubah Identitas e-learning } \\
\text { 5. Mengatur Tampilan halaman depan } \\
\text { 6. Mengubah thema }\end{array}$ & $\begin{array}{l}\text { Evi Yulianti, } \\
\text { M.SI } \\
\text { 3(tiga) Orang } \\
\text { Mahasiswa }\end{array}$ & $\begin{array}{l}\text { Ruang Rapat } \\
\text { Sekolah }\end{array}$ \\
\hline & $\begin{array}{l}\text { 1. Membuat kategori } \\
\text { 2. Membuat User } \\
\text { 3. Upload file } \\
\text { 4. Mengangkat status user } \\
\text { 5. Latihan membuat course baru }\end{array}$ & $\begin{array}{l}\text { Dasrial, M.Kom } \\
\text { 3(tiga) Orang } \\
\text { Mahasiswa }\end{array}$ & $\begin{array}{l}\text { Ruang Rapat } \\
\text { Sekolah }\end{array}$ \\
\hline
\end{tabular}

\subsection{Metode Pelaksanaan}

Pada Kegiatan ini, diuraikan rangkaian kegiatan Pengabdian Masyarakat adalah sebagai berikut :

\section{1) Lokasi Pelaksanaan}

Kegiatan Pengabdian Masyarakat ini dilaksanakan di SMP Negeri 36 Palembang, yang berlokasi di Jalan Ki Kemas Rindo No.89 Kertapati Palembang, Provinsi Sumatera Selatan telp (0711) 511238 Kode Pos 30258. 


\section{2) Waktu Pelaksanaan}

Kegiatan Pengabdian Masyarakat ini dilaksanakan selama 2 (dua) hari yaitu pertemuan dimulai sabtu tanggal, 30 mei 2015 dan sabtu tanggal 6 juni 2015.

\section{3) Jadwal Pelaksanaan Kegiatan}

Kegiatan Pengabdian Masyarakat ini akan dilakukan pembagian waktu pelaksanaannya yang terperinci sebagai berikut:

Tabel 2. Jadwal Pelaksanaan Kegiatan

\begin{tabular}{|l|l|l|l|l|}
\hline \multirow{2}{*}{ Nama Kegiatan } & \multicolumn{3}{|c|}{ Bulan } \\
\cline { 2 - 5 } & & $\mathbf{3 0}$ mei 2015 & $\mathbf{6}$ juni 2015 & $\mathbf{1 0 ~ j u n i ~ 2 0 1 5}$ \\
\hline Survey Lokasi & & & & \\
\hline Persiapan Kegiatan & & & & \\
\hline $\begin{array}{l}\text { Persiapan Materi yang } \\
\text { akan disampaikan } \\
\text { kepada perserta }\end{array}$ & & & & \\
pelatihan & & & \\
\hline Pembagian Tugas & & & \\
\hline $\begin{array}{l}\text { Persiapan Alat dan } \\
\text { Bahan Pelatihan }\end{array}$ & & & \\
(Modul) & & & & \\
\hline $\begin{array}{l}\text { Acara Kegiatan } \\
\text { Penyampaian materi } \\
\text { dan pelatihan }\end{array}$ & & & & \\
pembuatan Bahan ajar & & & & \\
\hline $\begin{array}{l}\text { Pelaporan Hasil } \\
\text { Pelatihan }\end{array}$ & & & & \\
\hline Evaluasi Pengabdian & & & & \\
Masyarakat & & & \\
\hline
\end{tabular}

\section{4) Rancangan Evaluasi}

Evaluasi Kegiatan pelatihan ini meliputi evaluasi dan produk. Evaluasi dilakukan mulai dari awal pelatihan, proses pelatihan, menyusun media, hingga mempresentasikan hasil dan menyerahkan hasil revisi.

Tabel 3. Instrumen Kelayakan Media Pembelajaran

\begin{tabular}{|c|c|c|c|}
\hline No & Indikator & Sub Indikator & $\begin{array}{l}\text { Jumlah } \\
\text { Butir }\end{array}$ \\
\hline \multirow[t]{6}{*}{1.} & \multirow[t]{6}{*}{ Materi } & 1. Kesesuaian dengan kompetensi & 5 \\
\hline & & $\begin{array}{l}\text { 2. Kesesuaian dengan tingkat } \\
\text { perkembangan perserta didik }\end{array}$ & 1 \\
\hline & & 3. Dorongan belajar mandiri & 2 \\
\hline & & 4. Pengorganisasian materi & 3 \\
\hline & & 5. Kelayakan Assesment & 6 \\
\hline & & Jumlah & 17 \\
\hline \multirow[t]{4}{*}{2.} & \multirow[t]{4}{*}{ Tampilan } & Kejelasan petunjuk & 2 \\
\hline & & 2. Daya tarik & 8 \\
\hline & & 3. Kejelasan tampilan & 3 \\
\hline & & Jumlah & 13 \\
\hline \multirow[t]{5}{*}{3.} & \multirow{5}{*}{$\begin{array}{l}\text { Pengorganisasian } \\
\text { Materi }\end{array}$} & Konsistensi & 3 \\
\hline & & Format & 4 \\
\hline & & Organisasi & 3 \\
\hline & & 4. $\quad$ Bentuk dan Ukuran Huruf & 2 \\
\hline & & Jumlah & 12 \\
\hline \multicolumn{3}{|c|}{ Jumlah butir angket } & 42 \\
\hline
\end{tabular}




\section{HASIL DAN PEMBAHASAN}

\subsection{Pencapaian Tujuaan}

Pencapaian tujuan kegiatan ini tidak dapat dilepas dari tahap-tahap kegiatan yang telah dilakukan . Langkah-langkah tersebut adalah :

Melakukan identifikasi masalah yang berhubungan dengan kemampuan guru dalam membuat maupun menggunakan media pembelajaran berbasis komputer. Hal ini dilakukan dengan melakukan diskusi dan wawancara dengan kepala sekolah dan wakil kepala sekolah urusan kurikulum.

\subsection{Jadwal Pelaksanan Acara Kegiatan}

Tabel dibawah ini menunjukkan jadwal kegiatan acara pelatihan yang diadakan diruang rapat SMP Negeri 36 Palembang yang berlangsung selama 2 (dua) hari.

Tabel 4. Jadwal Acara Kegiatan

\begin{tabular}{|c|c|c|c|c|c|}
\hline Pert & Pelaksanaan /Materi & $\begin{array}{l}\text { Tanggal } \\
\text { /Waktu }\end{array}$ & $\begin{array}{c}\text { Metode } \\
\text { Kegiatan }\end{array}$ & Pelaksanaan & Output \\
\hline 1. & $\begin{array}{l}\text { 1. Pengenalan Materi } \\
\text { Ms.Powerpoint } \\
\text { 2. Langkah-langkah } \\
\text { masuk/keluar Ms.Powerpoint } \\
\text { 3. Membuat Slide } \\
\text { 4. Langkah-langkah membuat } \\
\text { Presentasi } \\
\text { 5. Membuat Animasi Menu } \\
\text { Berjalan }\end{array}$ & $\begin{array}{l}30 \text { Mei } \\
2015 \text { Jam } \\
09.00- \\
12.00\end{array}$ & $\begin{array}{l}\text { Ceramah } \\
\text { Diskusi, } \\
\text { Praktek }\end{array}$ & Dasrial, M.Kom & $\begin{array}{l}\text { Peningkatan } \\
\text { Pengetahuan } \\
\text { bagi para guru } \\
\text { SMPN } 36 \text { dalam } \\
\text { pembuatan } \\
\text { bahan ajar } \\
\text { mengunakan Ms } \\
\text { Powerpoint }\end{array}$ \\
\hline 2. & $\begin{array}{l}\text { 1. Pengenalan Materi Ms.Excel } \\
\text { 2. Langkah-langkah } \\
\text { masuk/keluar Ms.Excel } \\
\text { 3. Memilih cell atau Range } \\
\text { 4. Mengatur tinggi row dan } \\
\text { column } \\
\text { 5. Menyimpan dan membuka } \\
\text { File } \\
\text { 6. Membuat Tabel } \\
\text { 7. Mengenalkan Formula Dasar } \\
\text { Ms.Excel } \\
\text { 8. Alamat Absolut, Fungsi } \\
\text { Lookup,Fungsi Logika } \\
\text { 9. Data Sort, Grafik dan gambar } \\
\text { 10. Mengatur Halaman dan Cetak }\end{array}$ & $\begin{array}{l}30 \text { Mei } \\
2015 \text { Jam } \\
13.00- \\
16.00\end{array}$ & $\begin{array}{l}\text { Ceramah } \\
\text { Diskusi, } \\
\text { Praktek }\end{array}$ & $\begin{array}{l}\text { Evi Yulianti, } \\
\text { M.SI }\end{array}$ & $\begin{array}{l}\text { Peningkatan } \\
\text { Pengetahuan } \\
\text { bagi para guru } \\
\text { SMPN } 36 \text { dalam } \\
\text { perhitungan dan } \\
\text { pengelolahan } \\
\text { data } \\
\text { mengunakan Ms } \\
\text { Excel }\end{array}$ \\
\hline \multirow[t]{2}{*}{3.} & $\begin{array}{l}\text { 1. Instalasi Program Elearning } \\
\text { (Moodle) } \\
\text { 2. Pengenalan Materi Elearning } \\
\text { 3. Mengenal Tampilan Portal e- } \\
\text { learning } \\
\text { 4. Mengubah Identitas e-learning } \\
\text { 5. Mengatur Tampilan halaman } \\
\text { depan } \\
\text { 6. Mengubah thema }\end{array}$ & $\begin{array}{l}\text { 06 Juni } \\
2015 \\
\text { Jam } \\
09.00- \\
12.00\end{array}$ & $\begin{array}{l}\text { Ceramah, } \\
\text { Diskusi, } \\
\text { Praktek }\end{array}$ & $\begin{array}{l}\text { Evi Yulianti, } \\
\text { M.SI }\end{array}$ & \multirow[t]{2}{*}{$\begin{array}{l}\text { Peningkatan } \\
\text { Pengetahuan } \\
\text { bagi para guru } \\
\text { SMPN } 36 \text { dalam } \\
\text { membuat bahan } \\
\text { ajar dapat } \\
\text { mengupload } \\
\text { materi dan video } \\
\text { menggunakan - } \\
\text { e-learning }\end{array}$} \\
\hline & $\begin{array}{l}\text { 1. Membuat kategori } \\
\text { 2. Membuat User } \\
\text { 3. Upload file } \\
\text { 4. Mengangkat status user } \\
\text { 5. Latihan membuat course baru }\end{array}$ & $\begin{array}{l}06 \text { Juni } \\
2015 \text { Jam } \\
13.00- \\
16.00\end{array}$ & $\begin{array}{l}\text { Ceramah, } \\
\text { Diskusi, } \\
\text { Praktek }\end{array}$ & Dasrial, M.Kom & \\
\hline
\end{tabular}




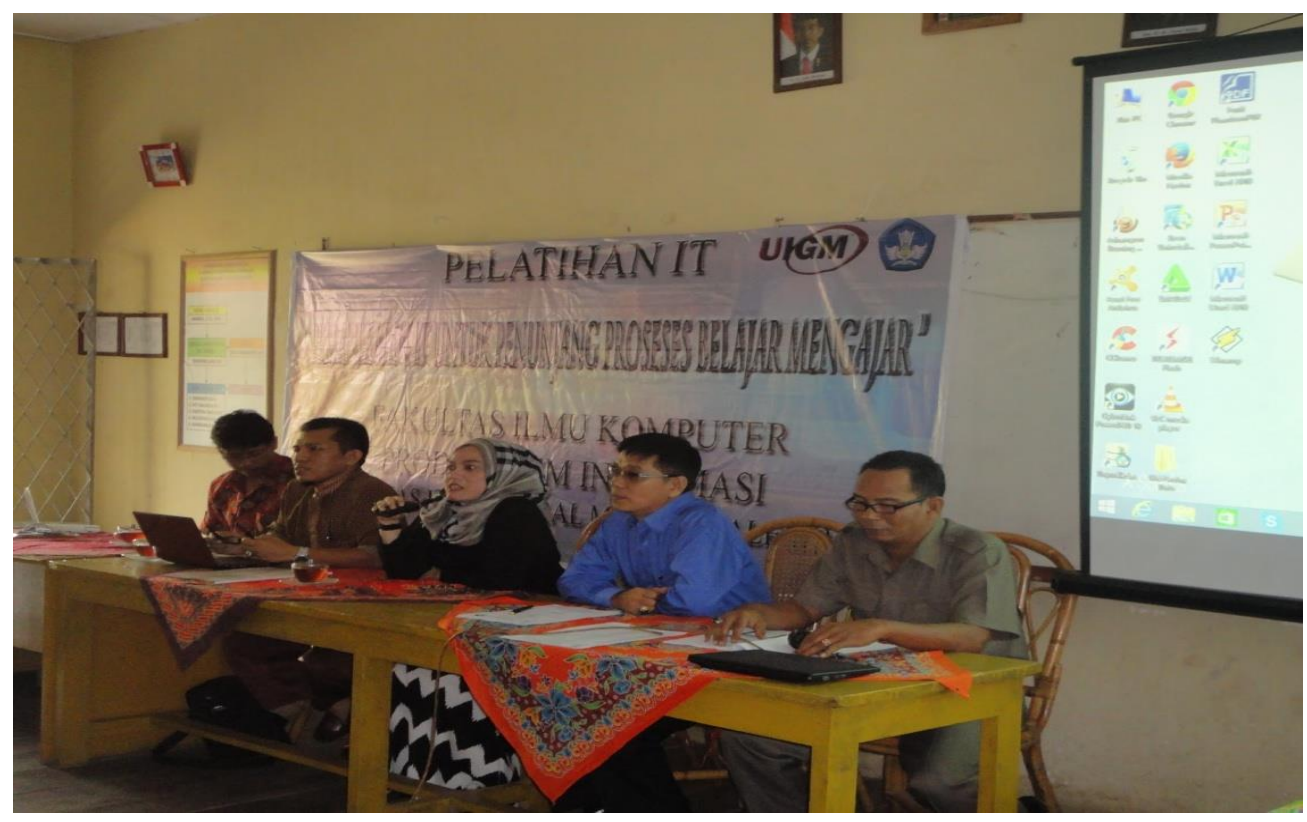

Gambar 1. Memberikan Pengarahan Terhadap Para Guru SMPN 36
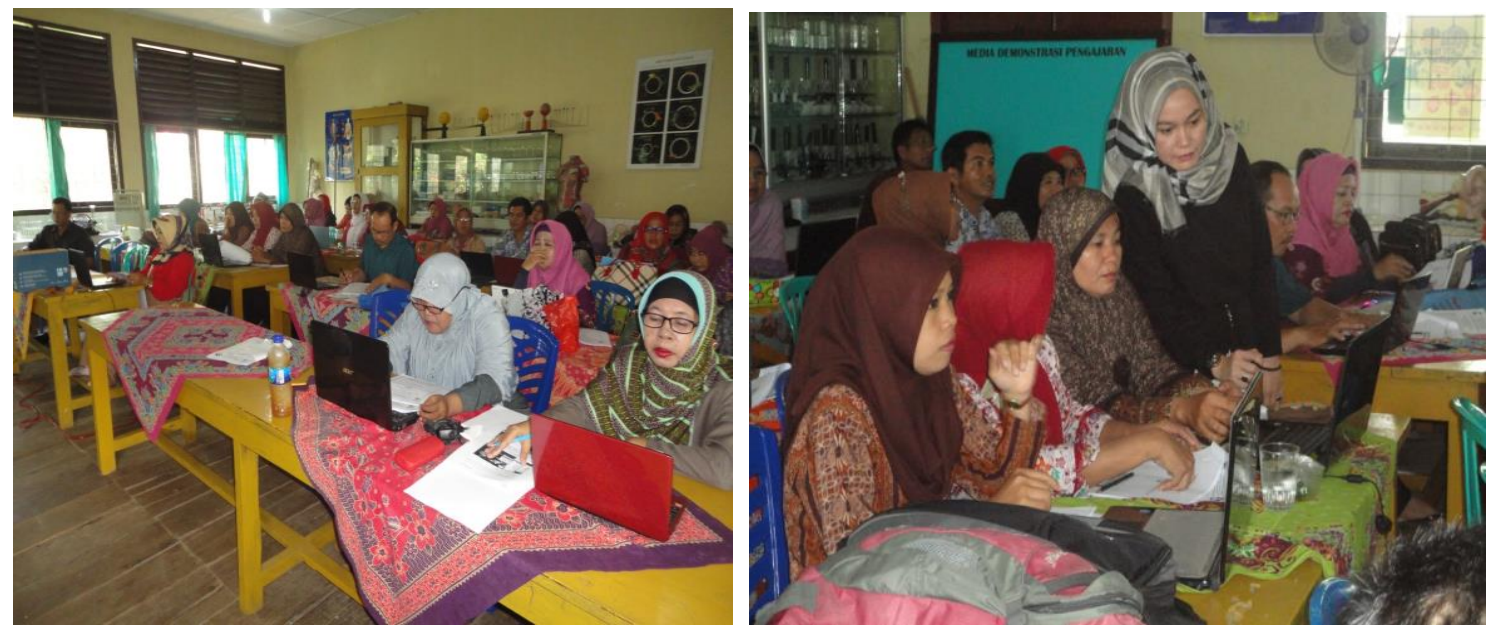

Gambar 2. Membimbing Para Guru SMPN 36

\section{KESIMPULAN}

Kegiatan pengabdian masyarakat berupa pelatihan pembuatan media Pembelajaran berbasis komputer di SMP Negeri 36 Palembang telah berhasil dilaksanakan dengan materi pelatihan dan penerapan media, pembuatan media dengan Powerpoint, Excel dan E-learning yang dilaksanakan selama 2 (dua) hari, 16 (enam belas ) jam. Indikator keberhasilan yang telah dicapai dalam pelatihan ini dapat dilihat dari pencapaian kompetensi guru (perserta pelatihan) yang dilihat dari pengamatan selama proses pelatihan yaitu : Perserta memahami dan menguasai prosedur pengembangan media mulai , tahap identifikasi, pengembangan, validasi, penerapan hingga evaluasi untuk mendapatkan produk akhir. Perserta mampu membuat bahan ajar dengan media dengan Powerpoint, Excel dan Elearning.

\section{SARAN}

Perlu dilakukan Pelatihan lanjutan sebagai upaya meningkatkan kemampuan guru dalam membuat media Pembelajaran berbasis komputer. SMP Negeri 36 Palembang perlu memprogramkan dan menseminarisasikan hasil pelatihan ini bagi guru-guru lain. Disamping itu fasilitasi dan penyediaan sarana prasaran pembelajaran akan sangat menentukan keberhasilan implementasi pembelajaran berbasis komputer sebagai upaya meningkatkan kualitas pembelajaran. 


\section{DAFTAR PUSTAKA}

Ismail. 2008. Strategi Pembelajaran Agama IslamBerbasis Paikem:Pembelajaran Aktif, Inovatif, Kreatif, Efektif, dan Menyenangkan. RaSAIL Media Group. Semarang

Ismaniati, Ch. 2001. Pengembangan Program Pengembangan Pembelajaran Berbantuan Komputer, FIP UNY. Yogyakarta

Nazarudin. 2010. Manajemen Pembelajaran: Implementasi Konsep, Karakteristik dan Metodologi Pendidikan Agama Islam. Teras. Jogjakarta

Hamalik, Oemar.2001. Kurikulum dan Pembelajaran. PT Bumi Aksara. Jakarta

Hamalik, Oemar. 2006. Proses Belajar Mengajar. PT Bumi Aksara. Jakarta

Pasaribu \& Simandjuntak. 1983.Proses Belajar Mengajar. Tarsito. Bandung 